\section{Penry v. Lynaugh (1989)}

Moira C. Dux

US Department of Veteran Affairs, Baltimore, MD, USA

\section{Definition}

In this case, the court decided that it was not always a "cruel and an unusual" punishment to execute an individual with mental retardation. This was determined by a review of societal views at the time (in 1989). Specifically, societal views necessitate the "evolving standards of decency" to determine what is cruel and unusual. Due to the fact that only a few states prohibited execution of an individual with mental retardations at that time, the court ruled that the generally accepted societal thought did not indicate that execution of an individual with mental retardation was indeed an extreme act and thus not ruled to be cruel and unusual. Moreover, the court ruled that the "cruel and unusual" clause of the Eighth Amendment necessitates case-by-case consideration. This decision was the result of a 5-4 ruling and was regarded as highly controversial. In fact, in 2002, the US Supreme Court ruled in the case of Atkins v. Virginia that execution of an individual with mental retardation is excessive and violates the Eighth Amendment.

\section{Cross-References}

Atkins v. Virginia

\section{References and Readings}

Denney, R. L. (2005). Criminal responsibility and other criminal forensic issues. In G. Larrabee (Ed.), Forensic neuropsychology: A scientific approach. New York: Oxford University Press.

Penry v. Lynaugh, 492 U.S. 1 (1989). 